Dewi Indah Maharani ${ }^{1}$, Moses Glorino Rumambo Pandin ${ }^{2}$

'Faculty of Economics and Business, 'Faculty of Cultural Studies,

Airlangga University Surabaya, Indonesia

Jl. Dr. Ir. H. Soekarno, Mulyorejo, Kec. Mulyorejo, City of Surabaya, East Java 60115

dewi.indah.maharani-2020@feb.unair.ac.id; moses.glorino@fib.unair.ac.id

\title{
Book Review: \\ THE SELF-CONCEPT OF PANCASILA (KONSEP DIRI PANCASILA)
}

Book title: The Self-Concept of Pancasila; Author: Rahmad Hidayat, Sumarto; Publishers: Literacyology Book Publishers; City of Publishing: Bengkulu, Indonesia; Edition: First Print, August 2020; Number of pages: 127 Pages; Book size: $21 \mathrm{~cm}$ x $29.7 \mathrm{~cm}$; ISBN: 978-62394458-0-5

The book with the title Pancasila Self-Concept was written to provide information as well as an overview of the importance of society to practice Pancasila. Rahmad Hidayat and Sumarto as writers, this opens knowledge to the public, especially the younger generation, how the process of Pancasila was established as the basis of the Indonesian State. The Pancasila Self-Concept is a book that describes the shape of the Indonesian nation's personality which is characterized by an attitude of loving the homeland, upholding the 1945 Constitution, and adhering to the principle of mutual cooperation. So, the book should be read and understood by the younger generation, in building the nation's character. Where at this time, the behavior of the Indonesian people has deviated from the values of Pancasila. This character is formed from the existence of self-knowledge of the ability of knowledge and its influence on the social environment. In forming this understanding, the need for awareness of the values of Pancasila to be applied in the implementation of social life in Indonesia. This is expected to have a positive impact in maintaining national harmony and unity.

\section{REVIEWS}

A book entitled Pancasila self-concept, written by Rahmad Hidayat and Sumarto in which they as writers are concerned with the changing behavior of Indonesian society today, which is seen as far from the values of Pancasila. In addition, the authors in the book aims to provide a clear picture of the importance of practicing Pancasila in the life of the nation and State.

The Pancasila Self-Concept book, published in 2020, is expected to be a reference reading millennial appeal to the young generation in Indonesia. So that it is hoped that the spirit of nationalism and patriotism of the young generation of future leaders will be responsible, fair and wise. The book contains substantial messages regarding the current condition of the Indonesian people in implementing the values of Pancasila. In addition, it also explains the 
importance of replicating the goals of the State so that they are in accordance with the values of Pancasila as the basis of the State.

The Pancasila Self-Concept book comprehensively discusses the reflection of Pancasila values on people's lives today. The thought that provides a psychological and historical explanation of the Pancasila text was formulated during the preparation for Indonesian independence. As the final ingredient, it is hoped that the values of Pancasila are not just texts that are read during the flag ceremony. However, Pancasila can become values and norms in aspects of the life of the nation and State.

This very philosophical book is quite interesting to read by all circles, especially today's young generation. Although there are grammatical errors, the language used is simple and easy to understand. However, this Pancasila self-concept book is very good to be read by government administrators, political elites, students, and other general public. This is because the writings presented in the book provide awareness of the importance of Pancasila values being practiced and implemented in the life of the nation and State. So later, it can make Indonesia a developed, and prosperous country to be on par with other nations in the world.

At the beginning of writing, the author points out that there is a decline in the practice of Pancasila values in the lives of Indonesian people today. The reality is that there has been a change in people's thinking at this time, which ultimately leads to a very severe behavior deviation. Deviations in behavior can be seen clearly where the harmony, unity, and togetherness of the community do not reflect the nation's life based on Pancasila.

The evidence presented is that the community is far from the foundation of Pancasila, it is stated on page 25. The author explains that the five precepts of Pancasila are the guidelines and basis of the Indonesian State. But in reality, today, the application of these values has decreased. There have been many phenomena of divisions between religions today. The increasing intolerance between religions marks this in carrying out their worship. Reports in the media stated that there had been church bombings in Surabaya and the burning of mosques in Papua. Yet if it is understood in-depth, every religion never teaches to do evil. The deviations that occur show the declining attitude of people's trust in practicing the first precepts of Pancasila in social life.

Furthermore, it is explained that the conflicts that occur are related to the decline of society in practicing the first precepts of Pancasila. On page 26, it is explained that the moral impact of society has strayed far at this time. The moral decline is marked by the increasing number of cases of murder, robbery, corruption, robbery, and harassment. As evidence of the 
abuse that took place, it was explained that the division of society caused by political differences was explained.

Other evidence described on page 26 clearly shows that the application of the fifth precepts of Pancasila has deviated considerably. This is marked by some people who do not get justice for their right to life. Currently, we can see the increasing inequality of social discrimination that occurs. We can see that there is a gap in life between the rich and the poor. At the same time, the essence has been explained in the 1945 Constitution, especially the fifth precept that there is justice for all Indonesian people.

However, the conflicts that occurred above cannot be solely blamed on the government. The need for us to reflect on ourselves by placing the individual to blame. When the spirit of nationalism grows in the individual, perhaps these cases can be avoided. In the five precepts of Pancasila, there is a deep meaning that aims to create goodness in the nation and State. Therefore, it is appropriate as an Indonesian society to play a role in maintaining and implementing every meaning contained in Pancasila. Consequently, it is suitable for the community to understand the self-concept of Pancasila to create a prosperous life for the Indonesian people.

Self-concept is defined as a form of personality that a person has. This personality has a vital role in determining or directing a person's behavior. A person's behavior appears as the implementation of a character born of a self-concept. In other words, a person's behavior, both positive and negative, arises because of the self-concept that is owned, so that it affects his personality. To recognize what self-concept is, the first thing we do is acknowledge and even assess our abilities. Efforts to evaluate yourself are part of the self-concept. Thus, self-concept can be interpreted as a view of oneself as a whole, including knowledge, expectations, and selfevaluation.

The self-concept in a person is formed due to the participation of the environment. Every individual who is born initially does not have a self-concept in him. This happens because they do not have the knowledge, expectations, and evaluations about themselves. In other words, at first birth, humans are like white paper that doesn't have any writing on it. However, the interaction that occurs results in the emergence of knowledge and experience.

As a positive self-concept, it is characterized by one's awareness of one's strengths and weaknesses. Then, with the weakness he has, without inferiority, he tries to improve it. This is different if someone has a negative self-concept. The self-concept is marked by only fixing someone without trying to fix their weaknesses. As a result, the individual has low self-esteem. 
There are three aspects of self-concept that Staines describes in (1), namely basic selfconcept, social self, and ideal self. Essential self-concept is to look at a person towards oneself related to one's status, role, and abilities. Social self-concept emphasizes self-assessment by others. The ideal self-concept, as a form of a picture of the hopes, desires, and needs to be achieved by oneself. self-concept in two aspects, namely psychological aspects and physical aspects (2). Psychological aspects relate to self-assessment of self-confidence, self-esteem, abilities and incompetence. While the physical aspect relates to appearance, gender and a sense of prestige when dealing with other people. In other words, the physical aspect relates to adaptation to the environment.

The description above relates to the individual's positive self-concept. While the negative, characterized by a sensitive attitude to receive criticism, happiness with praise, the emergence of feelings of pleasure in others, and an attitude tends to be pessimistic in competing. Self-concept is sensitive to criticism, characterized by an individual's irritability when getting criticism from others. In individuals who have this self-concept, criticism is judged as an attempt that aims to bring them down.

Self-concept is happy with praise, marked by the emergence of feelings of pleasure when receiving recognition. This self-concept judges that he is better than others underestimates others, and often criticizes the results of others. The third self-concept, namely the feeling of not being liked by others, is characterized by judging other people as enemies. This self-concept considers him as a victim. The final self-concept, namely a pessimistic attitude in competing, is characterized by the absence of a desire to compete with others.

Folker in (3) says that self-concept plays an important role in human life. This is because the self-concept has three functions for human life: maintenance of internal consistency, an interpretation of experience, and hope. As the maintenance of internal consistency, it can be interpreted as forming feelings. The feelings experienced by individuals related to harmony, familiarity will lead to good views, ideas or feelings. However, the opposite will be felt by individuals if they experience bad feelings. As an interpretation of experience, it relates to aspects of an individual's assessment of the events or events experienced. So, from this experience, how individuals perceive themselves. And lastly, as an expectation relates to how the individual perceives the expectations to be achieved.

Pancasila is the basic ideology of Indonesia, where Pancasila comes from the Sanskrit word, namely "panca" which means five, and the word "sila" which is interpreted as a principle or principal. Therefore, Pancasila is a formulation and guideline for all Indonesian people in 
living the nation's life and State. Pancasila was first delivered on June 1, 1945. Thus, every June 1 is designated as the birthday of Pancasila.

Character education needs to be done to shape Indonesian society, especially youth, to have a national identity. Youth is the hope of the nation because they are future leaders. Therefore, it is necessary to build youth's knowledge, skills, and character as a bright hope for Indonesia's future. In creating the nation's character, the main thing that needs to be built is nationalism. This is because, Nationalism is a character that the community must own as a form of unifying the nation.

The context of Pancasila as the basis of the State is a value system that binds and unifies each of the precepts. The five principles contained in Pancasila have an attachment to one goal. Although each precept essentially has its own function, it has one goal: creating a just and prosperous society.

Pancasila contains the meaning of the nation's view of life, which has a role as the basis of government activities. Pancasila was formed based on values about customs, culture, and religion in the Indonesian people's lives. In other words, Pancasila is formed from the views of the Indonesian people themselves.

Pancasila is said to be the nation's view of life, showing the soul and shape of Indonesia's personality. As the nation's view of life, Pancasila acts as a guide and as a guide in people's lives. In other words, Pancasila is used as a measure and criterion in culture and religious values in real life of Indonesian society.

Pancasila as the self-concept of society is an inseparable part. This is because the values of Pancasila exist in every aspect of religious, social, and social justice. Pancasila is a spiritual principle of the State, reflecting the values, norms, and good principles of Indonesian morality and law. Therefore, Pancasila has the main function as the basis of the State, where its manifestations are described in state laws.

Indonesia is a democracy based on law. Therefore, every aspect of the implementation and administration of the State has been regulated in the statutory system. In this sense, it shows that the implementation of the State is carried out based on the constitution or laws. The law regulates the division of power, high state institutions, the rights and obligations of citizens, and about social justice. All of these things are regulated in the Constitution of the State.

As the nation's ideology uPancasila However, the current situation has torn apart the value of wisdom in the deliberation of representatives. Currently, a lot is happening for the sake of practical political interests that have undermined the value of social justice. The value 
of social justice for all people can now be said to be just a slogan. This is due to creating a deep gulf between the rich and the poor which creates social jealousy.

As a result of the decline in the values of Pancasila in the lives of Indonesian people, globalization has occurred. On page 57, it is explained that globalization is defined as the occurrence of global social relations, which are then connected to each other. As a result of these relationships, events that occur in one place can also impact other places. Globalization will certainly lead to an increase in technology. Rapid technological advances, causing a decline in public morale. This is because the impact of globalization is that it is easier for foreign cultures to enter and be absorbed by the younger generation. This can be seen from the lifestyle of the current generation. This causes the value of Pancasila, which is related to civilized humanity, to decrease in people's lives.

Another sign of the decline of Pancasila values in the current generation's lifes the emergence of the nation's disintegration described on page 58. According to the Big Indonesian Dictionary, disintegration is a state that is not united and unified. Therefore, to prevent the nation's disintegration, it is necessary to instill Pancasila values in children from an early age. In addition, we need to always hold fast to Pancasila as the basis of a state that can unite pluralism. Therefore, to apply these values, it is necessary to have genuine intentions from the community. A strong intention to implement the values of Pancasila in the life of the nation and State.

The increasing prevalence of corruption marks the form of the decline in the values of Pancasila in the life of the nation today. Corruption itself is explained on page 59, comes from the word corruption which means rotten, damaged, destabilizes, abuses interests and bribes. In other words, corruption can be interpreted as an act carried out unreasonably and illegally by using a trust to gain one's own advantage. Corruption is a product that arises from the attitude of life of community groups that place money as the standard of truth and power.

Corruption itself is contrary to the 5th precept of Pancasila, namely justice for all Indonesian people. This fifth precept prioritizes the creation of justice for all people regardless of differences, by upholding justice for the people, creating a safe, peaceful and prosperous life for the Indonesian people. Therefore, to achieve this, it is necessary to create the values of harmony, harmony and balance regarding the rights and obligations of citizens. These values can be realized by not discriminating against religion, ethnicity, language, and people's socioeconomic status. In other words, all citizens must be treated fairly by their rights and obligations. 
The high level of corruption that occurs in Indonesia today has not shown the good practice of Pancasila in people's lives. In addition, the actions taken by law enforcement officers who are less professional and responsive show the values of Pancasila that are not appropriately implemented. In fact, if the practice of Pancasila is carried out correctly as a legal basis, all regulations must be obeyed.

In the style of delivery and the structure of the author's delivery, this aims to be able to re-apply the values of Pancasila in the life of today's society. The message conveyed by the author is especially for the younger generation in the 21 st century to understand the birth of Pancasila as the basis of the State. This is an important part because the life of today's young generation is more individual than prioritizing unity.

The book with the title Pancasila Self-Concept, provides awareness for the community of the need to re-apply the values of Pancasila as the nation's identity. Based on the description presented by the author, so many conflicts have arisen due to the loss of the nation's personality. Therefore, it is important for the public to read, especially the younger generation of Indonesia who has concern for the future of the Indonesian nation.

It is also able to tell how the impact that will arise if the practice of Pancasila values is not applied in people's lives. Starting from an explanation of the self-concept of Pancasila, it makes the reader understand what the self-concept is meant in Pancasila. In addition, it also tells how the challenges faced by the Indonesian people today, especially those faced by the younger generation. Although this self-concept book has explained the position of Pancasila in people's lives, there are still some weaknesses/shortcomings. The drawback that can be observed is the lack of the author in detail explaining how to form a Pancasila self-concept in people's lives.

This is considered to be still not contained in the self-concept book. What is expected, however from the book, can become an ideal reference for the younger generation in thinking and acting so that they can maintain and preserve the values of Pancasila. In addition, another shortcoming is, connecting the self-concept to the discussion of important parts of the book. In other words, there are still weaknesses in placing the position of self-concept in preventing negative actions. In fact, from generation to generation, the nation's culture has been increasingly eroded. Thus, a strong breakthrough is needed in implementing Pancasila.

However, making the book important for younger generations to read is paramount. This is because the young generation is a pillar of the progress of the Indonesian nation in the future. Therefore, it is necessary to encourage various parties to make this Pancasila self- 
concept book to be read by the younger generation. So, it is necessary to improve the presentation by adjusting the style of today's young generation. Where the younger generation prefers a language style that is not long-winded in its presentation, so the expression reduces interest from readers.

Based on the explanation of this Pancasila Self-Concept book, we can know that it is the shared responsibility of all people to return to the values of Pancasila, especially can be embedded in the body and soul of the young generation of the nation's successors. The generation of future leaders of the nation can make the State of Indonesia into a sovereign state and respected by other nations.

\section{REFERENCES}

1. Rachmat J. Jalaluddin. 2001. Intercultural Communities, Guide to Communicating with People of Different Cultures.

2. Hurlock EB. Personality development [Internet]. New York; London: McGraw-Hill; 1974. Available from: http://books.google.com/books?id=CN1-AAAAMAAJ

3. Burns RB. Self-Concept: Theory, measurement, development and behavior. Jakarta: Arcan. 1993;

\section{Author Biography}

The author, consists of two authors, namely Dr. Rahmad Hidayat, M.Ag., M.Pd. and Dr. Sumarto, M.Pd.I. Dr. Rahmad Hidayat, M.Ag., M.Pd as the first author, is the rector of IAIN Curup Kab. Rejang Lebong Prov. Bengkulu. The author was born in Sapan Kodya Sawahlunto, on: December 11, 1971. The author currently has a functional position as Head Lecturer. His service as a lecturer has been done for a long time in the field of Tarbiyah and Educational Sciences, which is 22 years. The author is a graduate of the Islamic Studies Doctoral Program at the State Islamic University of Sunan Kalijaga.

Sumarto, M.Pd.I., as the second author is a lecturer at IAIN Curup. The author was born in Tarutung on March 24, 1990. Education of the author, is a graduate of the Doctoral Program at UIN Sulthan Thaha Saifuddin Jambi in 2016. The author is also the founder of the Indonesian Literacy Foundation. Our Literacy Foundation Indonesia, is engaged in the development of knowledge. 